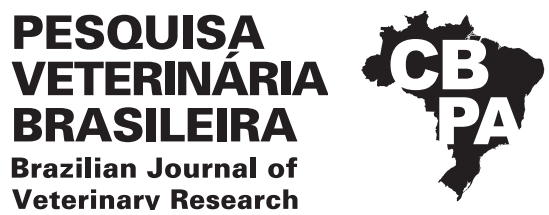

\title{
Investigation of Listeria monocytogenes, Salmonella enterica and Yersinia enterocolitica in pig carcasses in Southern Brazil ${ }^{1}$
}

\author{
Jalusa D. Kich² (D), Agnes I.A. Souza³ ${ }^{2}$ Júlia Montes², Mariana Meneguzzi², \\ Eduardo F. Costa ${ }^{4}$ (D) Arlei Coldebella ${ }^{2}$ (D) , Luis Gustavo Corbellini ${ }^{4}$ \\ and Marisa Cardoso ${ }^{4}$
}

\begin{abstract}
Kich J.D., Souza A.I.A., Montes J., Meneguzzi M., Costa E.F., Coldebella A., Corbellini L.G. \& Cardoso M. 2020. Investigation of Listeria monocytogenes, Salmonella enterica and Yersinia enterocolitica in pig carcasses in Southern Brazil. Pesquisa Veterinária Brasileira 40(10):781-790. Embrapa Suínos e Aves, BR-153 Km 110, Distrito de Tamanduá, Concórdia, SC 89715-899, Brazil. E-mail: jalusa.kich@embrapa.br

The intensification of pig production and advances in the sanitary control of herds profoundly changed the profile of risk attributed to pork consumption. In the actual scenario, most microorganisms related to macroscopic lesions observed in the post mortem inspection are not transmitted by food, while foodborne bacteria of importance to consumer health do not cause macroscopic lesions. In Brazil, the "Ministério da Agricultura, Pecuária e Abastecimento" requested a scientific opinion on the prioritizing of pathogens potentially transmitted by unprocessed pork. After conducting a qualitative risk assessment, only Salmonella enterica was classified as of high risk to consumers. The present study was part of the validation step of the risk assessment and aimed to investigate the frequency of S. enterica, Yersinia enterocolitica and Listeria monocytogenes and hygienic-sanitary indicators in pig carcasses of pigs rose under intensive production and slaughtered under the Federal Inspection System in three slaughterhouses located in Southern Brazil. Additionally, the antimicrobial resistance profile of the isolated pathogens was also investigated. A total of 378 carcasses were sampled by superficial sponges before the chilling step in three slaughterhouses. Samples were investigated for the presence of the three aforementioned pathogens and subjected to enumeration of Colony Formation Units $\left(\log \mathrm{CFU} . \mathrm{cm}^{-1}\right)$ of total aerobic mesophiles (TAM) and Enterobacteriaceae. Salmonella strains were tested by disc diffusion test for resistance to eleven antimicrobials. There were significantly statistical differences $(p<0.0001)$ on the median counts of both indicators between the slaughterhouses. The median of TAM was very close for Slaughterhouses A and B: $1.573 \log$ CFU. $\mathrm{cm}^{-1}$ and $1.6014 \log$ CFU.cm ${ }^{-1}$, respectively. While in Slaughterhouse C, a higher TAM median was detected (2.216 log CFU.cm $\left.{ }^{-1}\right)$. A similar profile was observed regarding to Enterobacteriaceae, and medians were calculated as follow: $-0.426 \log$ CFU.cm ${ }^{-1}$ in Slaughterhouse A; $0.2163 \log$ CFU.cm $^{-1}$ in B; and 0.633 log CFU.cm ${ }^{-1}$ in C. Regarding the pathogens investigated, L. monocytogenes was not detected and only one carcass from Slaughterhouse $\mathrm{C}$ was positive for $Y$. enterocolitica. Thus, the results suggest a very low prevalence of $L$. monocytogenes and $Y$. enterocolitica in the sampled population. A total of $65(17.2 \%)$ carcasses were positive for S. enterica, with a difference in frequencies between slaughterhouses and slaughter days. The prevalence of Salmonella positive carcasses was higher in the Slaughterhouse C (25.4\%; CI 95\% 19-32\%) in comparison with A (9.5\%; CI
\end{abstract}

\footnotetext{
${ }^{1}$ Received on May 25, 2020.

Accepted for publication on July 4, 2020.

${ }^{2}$ Embrapa Suínos e Aves, BR-153 Km 110, Distrito de Tamanduá, Concórdia, SC 89715-899, Brazil. E-mails: juliahmontes@gmail.com, mariana.meneguzzi@hotmail.com, arlei.coldebella@embrapa.br; *Corresponding author: jalusa.kich@embrapa.br
}

\footnotetext{
${ }^{3}$ Graduate Program in Veterinary Science, Faculdade de Veterinária, Universidade Federal do Rio Grande do Sul (UFRGS), Av. Bento Gonçalves 9090, Porto Alegre, RS 91540-000, Brazil. E-mail: agnes_isadora@hotmail.com

${ }^{4}$ Departamento de Medicina Veterinária Preventiva, Faculdade de Veterinária, Universidade Federal do Rio Grande do Sul (UFRGS), Av. Bento Gonçalves 9090, Porto Alegre, RS 90540-000, Brazil. E-mails: eduardo.costa@ufrgs.br, luis.corbellini@ufrgs.br, mcardoso@ufrgs.br
} 
95\% 9-14\%) and B (18.3\%; CI 95\% 12-24\%). There was no significantly statistical association between Enterobacteriaceae counts and Salmonella isolation on carcass surface $(\mathrm{p}=0.69)$. The slaughtering day, nested within the slaughterhouse, explains 31.3\% of Salmonella prevalence variability. $S$. Typhimurium (38.1\%) was the most prevalent, followed by $S$. Infantis (30.1\%). Among the 61 Salmonella strains tested for resistance to antimicrobials, 18 (31.6\%) were full-susceptible. No strain displayed resistance to azithromycin, ceftazidime, cefotaxime and meropenem. The highest resistance frequency was displayed to tetracycline $(54.1 \%)$, followed by ampicillin (50.82\%), nalidixic acid (42.62\%) and chloramphenicol (42.62). Multiresistance was detected in $52.54 \%$ of the, strains. In conclusion, $S$. enterica is more prevalent in pre-chill pig carcasses than $Y$. enterocolitica and L. monocytogenes and thus should be prioritized in monitoring and control programs at slaughter. Salmonella serovars varied among slaughterhouses and present significant differences in their resistance to antimicrobials. Slaughterhouses that present higher medians of TAM or Enterobacteriaceae in a monitoring period may have higher S. enterica prevalences as well. However, there is a high variation of S. enterica prevalence among slaughter days, which cannot be always related to the hygienic indicators counts observed on a given day.

INDEX TERMS: Listeria monocytogenes, Salmonella enterica, Yersinia enterocolitica, pig carcasses, pork, pigs, antimicrobial resistance, Brazil.

RESUMO.- [Pesquisa de Listeria monocytogenes, Salmonella
enterica and Yersinia enterocolitica em carcaças de suínos no sul do Brasil.] A intensificação da produção de suínos e os avanços no controle sanitário dos rebanhos alterou de forma importante o perfil de risco do consumo de carne suína. No cenário atual, a maioria dos microrganismos causadores de lesões macroscópicas detectáveis na inspeção post mortem não são transmissíveis por alimentos, enquanto bactérias de importância como causadoras de doenças transmitidas por alimentos não causam lesões macroscópicas. No Brasil, o Ministério da Agricultura, Pecuária e Abastecimento solicitou uma opinião científica sobre a priorização de patógenos potencialmente transmitidos pela carne suína in natura. Após conduzir uma avaliação de risco qualitativa, apenas Salmonella enterica foi classificada como de alto risco para o consumidor. 0 presente estudo foi parte da etapa de validação da avaliação de risco e objetivou: investigar a frequência de S. enterica, Yersinia enterocolitica e Listeria. monocytogenes; e enumerar indicadores higiênico-sanitários em carcaças de suínos abatidos sob inspeção federal em frigoríficos dedicados ao abate de suínos sob sistema intensivo de criação no sul do Brasil. Além disso, o perfil de resistência a antimicrobianos dos patógenos isolados foi investigado. A superfície de um total de 378 carcaças foi amostrada por esponjas, na etapa de pré-resfriamento em três matadouros frigoríficos (A, B, C). As amostras foram investigadas quanto à presença dos três patógenos acima mencionados e quanto à enumeração de Unidades Formadoras de Colônia (log UFC.cm ${ }^{-1}$ ) de mesófilos aeróbios totais (MAT) e Enterobacteriaceae. As cepas isoladas de Salmonella foram testadas quanto à resistência a onze antimicrobianos pela técnica de disco difusão. As medianas de contagem de ambos os indicadores apresentaram diferença significativa $(p<0,0001)$ entre matadouros-frigoríficos. A mediana de MAT foi bastante próxima para A e B $(1,573$ log UFC.cm ${ }^{-1}$ e 1,6014 log UFC.cm ${ }^{-1}$, respectivamente), enquanto em $\mathrm{C}$ uma mediana de MAT mais elevada foi determinada $\left(2,216 \log \mathrm{CFU} \cdot \mathrm{cm}^{-1}\right)$. Um perfil semelhante foi observado em relação a Enterobacteriaceae, sendo as medianas calculadas para A, B e C, respectivamente: $-0,426 \log$ CFU.cm ${ }^{-1} ; 0,2163$ $\log$ UFC.cm ${ }^{-1}$; e 0,633 log UFC.cm ${ }^{-1}$. Em relação aos patógenos investigados, L. monocytogenes não foi detectada e apenas uma carcaça, do Matadouro C, foi positiva para Y. enterocolitica. Portanto, os resultados sugerem uma prevalência muito baixa desses patógenos na população amostrada. Em um total de $65(17,2 \%)$ carcaças houve isolamento de S. enterica, com diferença nas frequências observadas entre matadouros e dias de abate. A prevalência de carcaças positivas para $S$. enterica foi maior no Matadouro C (25,4\%; IC95\% 19-32\%) em comparação com A (9,5\%; IC95\% 9-14\%) e B (18,3\%; IC95\% 12-24\%). Não houve associação estatística entre o número de Enterobacteriaceae e o isolamento de $S$. enterica na superfície das carcaças $(\mathrm{p}=0,69)$. 0 dia de abate agrupado por frigorífico explica $31,3 \%$ da variação na prevalência de Salmonella. O sorovar mais frequente de S. enterica foi Typhimurium $(38,1 \%)$ seguido de $S$. Infantis $(30,1 \%)$. Entre as 61 cepas de $S$. enterica testadas quanto à resistência a antimicrobianos, $18(31,6 \%)$ foram totalmente suscetíveis aos antimicrobianos testados. Nenhuma cepa apresentou resistência a azitromicina, ceftazidima, cefotaxima e meropenem. As maiores frequências de resistência foram demonstradas contra tetraciclina $(54,1 \%)$, ampicilina $(50,8 \%)$, ácido nalidíxico $(42,62 \%)$ e cloranfenicol $(42,62 \%)$. Em $52,54 \%$ das cepas foi detectada multi-resistência. Em conclusão, S. enterica é mais prevalente em carcaças suínas no pré-resfriamento do que $Y$. enterocolitica e L. monocytogenes. Portanto, S. enterica deve ser priorizada em programas de monitoramento e controle ao abate. Os sorovares de Salmonella variam entre matadouros e apresentam diferenças significativas na resistência a antimicrobianos. Matadouros de suínos que apresentam medianas de MAT e Enterobacteriaceae num período de monitoramento podem apresentar também prevalências mais de altas de presença de S. enterica. Entretanto, há uma alta variabilidade na frequência de S. enterica entre dias de abate, e nem sempre há relação entre essa frequência e a contagem de indicadores higiênico-sanitários determinados num determinado dia.

TERMOS DE INDEXAÇÃO: Carne suína, carcaças de suínos, Salmonella enterica, Listeria monocytogenes, Yersinia enterocolitica, resistência a antimicrobianos, suínos, Brasil. 


\section{INTRODUCTION}

Meat inspection aims to protect the consumer's health by detecting and preventing hazards, which may be transmitted by meat (FAO 2000). The identification of meat unsuitable for human consumption has traditionally been performed by post mortem inspection of carcasses and viscera, which are subjected to visual examination, palpation and incisions for detecting lesions. The intensification of pig production and advances in the sanitary control of herds, however, profoundly changed the profile of risk attributed to pork consumption. While in the past parasitic diseases were the most important hazards transmitted by pork, nowadays parasites are very well controlled in the animal production phase with rare evidence of lesions. In the actual scenario, most microorganisms related to macroscopic lesions observed in the post mortem inspection are not transmitted by food; most of them cause animal diseases or are related to occupational exposure (EFSA 2011). Data collected from 2012 to 2014 in all Brazilian slaughterhouses under the Federal Inspection System demonstrated that cysticercosis, which had been an important zoonosis in the past, was the cause of only 9.2 condemnations per million pigs slaughtered in this period. Moreover, $74.5 \%$ of the detections occurred in only one slaughterhouse, indicating an epidemiological profile found in a restricted geographical area (Kich et al. 2019).

Foodborne bacteria of importance to consumer health, in turn, do not cause lesions and thus are not detectable by the technics adopted in the post mortem inspection (EFSA 2011). In addition, traditional inspection system practices, such as palpation and incision, can lead to the transfer of these bacteria between carcasses, the environment and employees (Buncic et al. 2014). As long as supported by scientific evidences, several countries have changed some traditional inspection practices, and adopted a risk-based meat inspection (EFSA 2011). In Brazil, the "Ministério da Agricultura, Pecuária e Abastecimento" (MAPA) requested from "Embrapa Suínos e Aves" a scientific opinion on this topic; in order to achieve this goal a multidisciplinary scientific project was conducted. The study aimed ultimately at generating scientific evidences to support decisions to be taken by the risk manager regarding changes in the meat inspection system. The first step of the project was a qualitative risk assessment for the prioritization of biological hazards transmissible to humans by pork (Costa et al. 2020), in which only Salmonella enterica was classified as of high risk to consumers. Other bacteria, such as Yersinia enterocolitica and Listeria monocytogenes, which are reported as possible causes of foodborne diseases transmitted by pork, were not prioritized in the risk assessment. However, Y. enterocolitica is often carried in slaughtered pig tonsils and can contaminate carcasses during processing (Drummond et al. 2012), while ready-to-eat pork products may be the vehicle of L. monocytogenes in foodborne cases (WHO 2018a). The presence of bacterial hazards in carcasses in turn is greatly influenced by the quality of the process and self-control programs implemented at slaughterhouses (Pearce et al. 2004, Arguello et al. 2013). The process hygiene has been monitored by the enumeration of hygienic-sanitary indicators, such as mesophilic aerobes and Enterobacteriaceae, since these bacteria can be eliminated by proper hygiene and sanitation procedures during slaughtering (Ghafir et al. 2008). Therefore, the investigation of these three pathogens and two hygienic-sanitary indicators (mesophilic aerobes and Enterobacteriaceae) was kept in the present study, which will be a part of the validation step that follows the qualitative risk assessment.

In addition to the risk posed by their presence in pork, pathogenic bacteria carrying antimicrobial resistance genes have been a growing concern to consumer's health. The hazard of multi-resistant strains selection by the antimicrobial use in animals has been stressed worldwide (WHO 2018b). Resistance to antimicrobials used for treatment of human diseases has been reported in foodborne pathogens, such as S. enterica isolated from swine (Lopes et al. 2015, McDermott et al. 2016, Cameron-Veas et al. 2018, Wang et al. 2019), highlighting the importance of monitoring the resistance of this pathogen. In this sense, gathering information of antimicrobial resistance profile of bacteria isolated from animals and animal products belongs to the goals of the antimicrobial resistance monitoring and control program launched in Brazil (Brasil 2018).

Therefore, the present study aimed to investigate the frequency of S. enterica, Y. enterocolitica and L. monocytogenes and hygienic-sanitary indicators in pig carcasses slaughtered under the Federal Inspection System in three slaughterhouses in Southern Brazil. This investigation was one of the steps for the development of the scientific opinion on the adoption of a risk-based inspection of pork in the scope of the Federal Meat Inspection System. Additionally, the antimicrobial resistance profile of the isolated pathogens was also investigated.

\section{MATERIALS AND METHODS}

Study design. The sample size calculation considered the minimum number of carcass samples needed to determine the prevalence of bacterial pathogens listed as important in pig carcasses. The parameters used to calculate a simple random sample were: infinite population, $95 \%$ confidence level, $6 \%$ absolute precision and $50 \%$ prevalence. A previous study (Corbellini et al. 2016) showed an important effect of the day of sampling on the variation of Salmonella prevalence in pig carcasses. The design effect (Deff) of sampling day was estimated in 1.42 in this study (Corbellini et al. 2016). Thus, this inflation factor was applied to correct the number of samples, resulting in a total of 378 carcasses to be analyzed. The Brazilian swine production system includes producers integrated into large agro-industries, producers who participate in a cooperative system and independent farmers who deliver finished animals to slaughterhouses. In order to achieve representativeness of the sample, the total number of carcasses was divided equally $(\mathrm{n}=126)$ among three slaughterhouses $(A, B, C)$, which represent the aforementioned three modes of swine production. Slaughterhouse A was part of a cooperative system; approximately 4,600 pigs were slaughtered daily. In Slaughterhouse B, a similar number of pigs $(4,200 /$ day $)$ were slaughtered, which were delivered by farmers engaged in an integration system with the company. The Slaughterhouse $\mathrm{C}$ received pigs from independent farmers, and slaughtered 900 pigs daily. In general, the moderate variation between clusters (sampling days) implies that the addition of sample units on a given day will not add much to the sample's representativeness, being more important to distribute the sample units in as many days as possible. Thus, six weekly sampling events were carried out in each of the slaughterhouses, with 21 carcasses sampled per event. Sampling was always conducted in the morning shift, with the first carcass sampled being that corresponding to the first slaughtered animal. The other samples were collected systematically in an interval of 35 carcasses. 
Sample collection and analysis. Carcasses were sampled at the pre-chill step using individual sterile abrasive sponges (NASCO ${ }^{\circledR}$ ) rubbed in an area of $100 \mathrm{~cm}^{2}$ from each: loin, jowl, ham and belly (Brasil 2007). The four sponges were pooled in sterile plastic bags and constituted the carcass sample, which was kept refrigerated until processing. To each carcass sample, $100 \mathrm{~mL}$ of $1 \%$ Buffered Peptone Water (BPW 1\%) were added; the suspension was then homogenized and used for the enumeration of hygienic indicators: total aerobic mesophiles (TAM) and Enterobacteriaceae; and detection of pathogens: Salmonella enterica, Yersinia enterocolitica and Listeria monocytogenes.

The enumeration of TAM and Enterobacteriaceae was performed in duplicate, in Petrifilm ${ }^{\mathrm{TM}}$ Aerobic Count Plates (3M Company) and Petrifilm ${ }^{\mathrm{TM}}$ Enterobacteriaceae Count Plates (3M Company), respectively, following the manufacturer's recommendations. After incubation at $37^{\circ} \mathrm{C}$ for $48 \mathrm{~h}$, typical colonies were counted and the result was multiplied by 0.25 to achieve the number of colony forming units ( $\mathrm{CFU}$ ) per $\mathrm{cm}^{2}$ of carcass surface.

S. enterica was investigated following the ISO 6579:2002 Amendment 1:2007 protocol (ISO 2007), using Xylose-LysineDeoxycholate agar (Merck) and Brilliant Green Phenol Red Lactose Sucrose agar (Merck) for the selective differential isolation step. Typical colonies were confirmed by their biochemical profile and agglutination with somatic polyvalent serum (Probac). The isolates confirmed as S. enterica were sent for serotyping at the "Fundação Instituto Oswaldo Cruz" (Fiocruz).

The detection of $Y$. enterocolitica was performed according to the methodology of the American Public Health Association (Weagant \& Feng 2001). Briefly, $1 \mathrm{~mL}$ of the sample suspension was added to $9 \mathrm{~mL}$ of Peptone Sorbitol Bile broth (PSB, Himedia) and incubated for 10 days at $10^{\circ} \mathrm{C}$. After this period, $10 \mu \mathrm{L}$ of the culture was transferred to $100 \mu \mathrm{L}$ of either $0.5 \%$ potassium hydroxide $(\mathrm{KOH})$ or $\mathrm{NaCl} 0.5 \%$ solutions. After homogenization for five seconds, an aliquot was immediately transferred to Cefsulodin-Irgasan-Novobiocin agar (Fluka) and to MacConkey agar (Oxoid) plates, and incubated at $30^{\circ} \mathrm{C}$ for $24 \mathrm{~h}$. Typical colonies were subjected to identification by Matrixassisted Laser Desorption Ionization Time-of-flight (MALDI-TOFF).

L. monocytogenes was investigated according to the IN62 (Brasil 2003) protocol. An aliquot of $1 \mathrm{~mL}$ of the sample suspension was added to $9 \mathrm{~mL}$ of Enrichment Broth for Listeria (UVM). After incubation at $30 \pm 1^{\circ} \mathrm{C}$ for $24 \mathrm{~h}$, an aliquot $(100 \mu \mathrm{L})$ was transferred to $9.9 \mathrm{~mL}$ of Fraser broth (Merck) and incubated at $30 \pm 1^{\circ} \mathrm{C}$ for $24 \mathrm{~h}$. Afterwards, aliquots were transferred to Tryptose agar with Nalidixic Acid, Palcam agar (Oxoid) and Chromocult ${ }^{\odot}$ Listeria Selective Agar acc. to Agosti and Otttaviani (ALOA, Merck). After incubation at $30^{\circ} \mathrm{C} \pm 1^{\circ} \mathrm{C}$ for $48 \mathrm{~h}$, typical colonies were identified by biochemical tests and CAMP test (Silva et al. 2010).

Antimicrobial susceptibility testing. S. enterica isolates were tested for antimicrobial susceptibility against eleven different antimicrobials. The agar disc diffusion method was performed and evaluated according to the specifications of the Clinical and Laboratory Standards Institute (CLSI) documents VET01-S3 and M100-S26 (CLSI 2015, 2016). The following discs (Oxoid) were used: ampicillin $(10 \mu \mathrm{g})$; azithromycin $(15 \mu \mathrm{g})$; cefotaxime $(30 \mu \mathrm{g})$; ceftazidime $(30 \mu \mathrm{g})$; chloramphenicol $(30 \mu \mathrm{g})$; ciprofloxacin $(5 \mu \mathrm{g})$; gentamicin $(10 \mu \mathrm{g})$, meropenem $(10 \mu \mathrm{g})$; nalidixic acid $(30 \mu \mathrm{g})$; tetracycline $(30 \mu \mathrm{g})$; trimethoprim $(5 \mu \mathrm{g})$. Escherichia coli ATCC $^{\odot}$ 25922 was used as a reference strain for quality control purposes. Antimicrobial multi-resistance was defined as resistance to three or more classes of antimicrobials (CLSI 2016).
Data analysis. The proportions of slaughterhouses in the quantiles of log CFU of mesophilic and Enterobacteriaceae counts, box-plot with the distribution of these indicators and Kruskal-Wallis test to assess if there are differences in the median counts of these indicators between slaughterhouses were made with the function Desc of the package DescTools (Signorell 2020) in R environment. The prevalence of Salmonella in each slaughterhouse was estimated using the package survey (Lumley 2020) in R environment.

An intercept-only multilevel logistic model that predicts the prevalence conditional to slaughterhouse and day of sampling was made in which the random effect was the day nested within slaughterhouse. The predicted conditional prevalence for each day of sampling within slaughterhouse was extracted from the model estimates. The model dimension has 18 subjects (i.e. the day of sampling, six in each selected slaughterhouse) with 21 observations per subject (21 carcasses in each day). The intra cluster correlation (ICC) was given by:

$$
I C C=\frac{\sigma_{0}^{2}}{\sigma_{0}^{2}+\frac{\pi^{2}}{3}}
$$

Where $\sigma_{0}^{2}$ is the between-cluster variance (i.e., the variance between days nested within slaughterhouse) and $\left(\sigma_{0}^{2}+\frac{\pi^{2}}{3}\right)$ is

The same model structure was used to check the effect of Enterobacteriaceae counts ( $\log$ CFU.cm ${ }^{-1}$ ) on the Salmonella isolation, and the ICC was calculated using the same formula described above. This model estimates the average effect of Enterobacteriaceae (fixed-effect) as well as its effect conditional to the day of sampling and slaughterhouse, i.e., the model generates 18 estimates for each day of sampling nested within slaughterhouse (random-effects).

The multilevel logistic models were analyzed with SAS Studio using the procedure PROC GLIMMIX. A significance level of 0.05 was considered for all statistical tests.

The antimicrobial susceptibility testing was analyzed using Fisher's exact test to identify its association with serotype and slaughterhouse. The procedure PROC FREQ from SAS 9.3 (SAS 2012) was used to do this evaluation.

\section{RESULTS}

The distributions of log CFU of TAM and Enterobacteriaceae counts and the proportion of slaughterhouse in the quantiles of log counts are demonstrated in Figure 1 and 2 . There were significantly statistical differences $(\mathrm{p}<0.0001)$ on the median counts of both indicators between the slaughterhouses. The median of TAM was very close for Slaughterhouses A and B: $1.573 \log$ CFU.cm ${ }^{-1}$ and $1.6014 \log$ CFU.cm ${ }^{-1}$, respectively. While in Slaughterhouse $\mathrm{C}$, a higher TAM median was detected (2.216 log CFU.cm ${ }^{-1}$ ). A similar profile was observed regarding to Enterobacteriaceae, and medians were calculated as follow: $-0.426 \log$ CFU.cm ${ }^{-1}$ in Slaughterhouse A; 0.2163 log CFU.cm ${ }^{-1}$ in B; and $0.633 \log$ CFU.cm ${ }^{-1}$ in C. For both hygienic indicators, in Slaughterhouse $C$ the collected data were concentrated in the fourth and fifth quantiles, while in A and B there was a concentration in the first and second quantiles.

Regarding the pathogens investigated, Listeria monocytogenes was not detected and only one carcass from Slaughterhouse C was positive for Yersinia enterocolitica. A total of 65 $(17.2 \%)$ carcasses were positive for Salmonella enterica, 
with a difference in frequencies between slaughterhouses and slaughter days. The prevalence of Salmonella positive carcasses was higher in the Slaughterhouse C (25.4\%; CI 95\% $19-32 \%)$ in comparison with A (9.5\%; CI 95\% 9-14\%) and B (18.3\%; CI 95\% 12-24\%). Only in Slaughterhouse C was $S$. enterica detected in all slaughter days.

The Salmonella prevalence conditional to the day of sampling and slaughterhouse estimated by the model was $17.7 \%$ and the between-cluster variance estimates was 1.67 . The resulted ICC was 33.6\% [1.67/(1.67+9.9/3)], which means the between-cluster (day of slaughtering nested within the slaughterhouse) variability in the prevalence of Salmonella on the carcasses. Table 1 depicts the predicted and observed prevalence in each day of sampling and model estimates. It is possible to observe a marked variation of the prevalence among days.

There was no significantly statistical association between Enterobacteriaceae counts and Salmonella isolation on carcass surface ( $\mathrm{p}=0.69$, Table 2$)$. The between-cluster variance estimates was 1.50, resulting in an ICC value of 31.3\% [1.50/ $(1.50+9.9 / 3)]$, which demonstrate the between-cluster (day of sampling nested within slaughterhouse) variability in the effect of Enterobacteriaceae counts on the prevalence of Salmonella. There were three statistically significant days nested within slaughterhouses (random intercepts), which are demonstrated in Table 2. These results mean that in these days the probability of isolation of Salmonella was significantly different (higher) than the average probability of Salmonella isolation given the Enterobacteriaceae count.
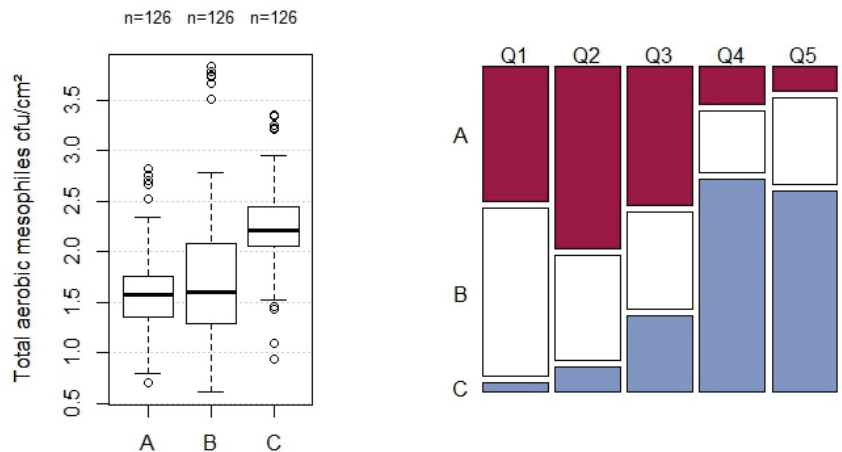

Fig.1. Box plotand quantile distribution (Q1-Q5) of total aerobic mesophiles counts on pig pre-chill carcasses in three slaughterhouses (A, B, C).
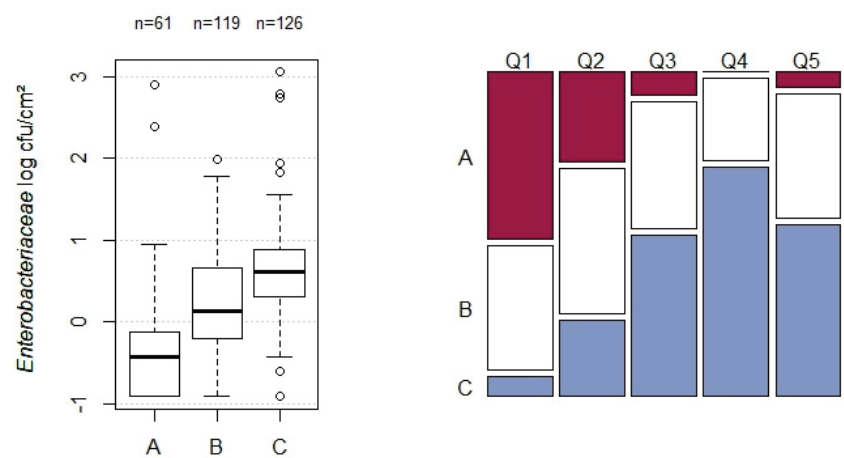

Fig.2. Box plot and quantile distribution (Q1-Q5) of Enterobacteriaceae (II) counts on pig pre-chill carcasses in three slaughterhouses $(A, B, C)$.

Table 1. Observed Salmonella prevalence and predicted prevalence estimated by the model on pig pre-chill carcasses in each day of sampling conducted in three slaughterhouses in southern Brazil

\begin{tabular}{|c|c|c|c|c|c|c|c|}
\hline \multirow[b]{2}{*}{ Model effect } & \multirow[b]{2}{*}{ Slaughterhouse } & \multirow[b]{2}{*}{$\begin{array}{c}\text { Day of } \\
\text { sampling }\end{array}$} & \multicolumn{3}{|c|}{ Model estimates } & \multicolumn{2}{|c|}{ Observed data } \\
\hline & & & Estimate & SE & Prevalence & $\begin{array}{l}\text { No. Salmonella positive } \\
(\mathrm{n}=21 / \mathrm{day})\end{array}$ & Prevalence \\
\hline Fixed effect intercept & . & . & -1.89 & 0.35 & - & - & - \\
\hline \multirow[t]{18}{*}{ Random effect intercept } & A & 1 & -1.34 & 0.88 & $3.8 \%$ & 0 & $0.0 \%$ \\
\hline & A & 2 & -1.34 & 0.88 & $3.8 \%$ & 0 & $0.0 \%$ \\
\hline & $\mathrm{A}$ & 3 & -0.27 & 0.68 & $10.3 \%$ & 2 & $9.5 \%$ \\
\hline & $\mathrm{A}$ & 4 & -0.27 & 0.68 & $10.3 \%$ & 2 & $9.5 \%$ \\
\hline & A & 5 & -0.27 & 0.68 & $10.3 \%$ & 2 & $9.5 \%$ \\
\hline & $\mathrm{A}$ & 6 & 0.85 & 0.56 & $26.1 \%$ & 6 & $28.6 \%$ \\
\hline & B & 1 & -1.34 & 0.88 & $3.8 \%$ & 0 & $0.0 \%$ \\
\hline & $\mathrm{B}$ & 2 & -1.34 & 0.88 & $3.8 \%$ & 0 & $0.0 \%$ \\
\hline & $\mathrm{B}$ & 3 & 0.37 & 0.60 & $18.0 \%$ & 4 & $19.0 \%$ \\
\hline & $\mathrm{B}$ & 4 & -0.27 & 0.68 & $10.3 \%$ & 2 & $9.5 \%$ \\
\hline & $\mathrm{B}$ & 5 & 0.37 & 0.60 & $18.0 \%$ & 4 & $19.0 \%$ \\
\hline & B & 6 & 2.12 & 0.52 & $55.8 \%$ & 13 & $61.9 \%$ \\
\hline & $\mathrm{C}$ & 1 & 2.12 & 0.52 & $55.8 \%$ & 13 & $61.9 \%$ \\
\hline & $\mathrm{C}$ & 2 & -0.72 & 0.76 & $6.8 \%$ & 1 & $4.8 \%$ \\
\hline & $\mathrm{C}$ & 3 & -0.27 & 0.68 & $10.3 \%$ & 2 & $9.5 \%$ \\
\hline & $\mathrm{C}$ & 4 & 0.08 & 0.63 & $14.1 \%$ & 3 & $14.3 \%$ \\
\hline & $\mathrm{C}$ & 5 & 1.78 & 0.52 & $47.3 \%$ & 11 & $52.4 \%$ \\
\hline & $\mathrm{C}$ & 6 & -0.27 & 0.68 & $10.3 \%$ & 2 & $9.5 \%$ \\
\hline Average prevalence & & & & & $17.7 \%$ & & $17.7 \%$ \\
\hline
\end{tabular}


Among the 63 isolates of $S$. enterica subjected to serotyping, $S$. Typhimurium (38.1\%) was the most prevalent, followed by $S$. Infantis $(30.1 \%)$. The profile of serovars found varied between slaughterhouses, with $S$. Typhimurium being significantly more prevalent $(\mathrm{P}<0.0001)$ in Slaughterhouses $\mathrm{A}$ and $\mathrm{B}$ than in $\mathrm{C}$ (Table 3 ). In Slaughterhouse $\mathrm{C}, \mathrm{S}$. Infantis was the most prevalent serovar.

Among the 61 Salmonella strains tested for resistance to antimicrobials, 18 (31.6\%) were full-susceptible (Table 4). No strain displayed resistance to azithromycin, ceftazidime, cefotaxime and meropenem. The highest resistance frequency was displayed to tetracycline (54.1\%), followed by ampicillin (50.82\%), nalidixic acid (42.62\%) and chloramphenicol (42.62). Multi-resistance was detected in $52.54 \%$ of the strains; in most cases $(62.5 \%)$ the MDR profile included tetracycline, ampicillin and chloramphenicol. The association between the serovars with the resistance frequency demonstrated that $S$. Typhimurium presented significantly more resistance $(\mathrm{P}<0.05)$ to almost all antimicrobials than the other serovars. Therefore, the greater antimicrobial resistance frequencies were observed in slaughterhouses, in which $S$. Typhimurium was isolated.

\section{DISCUSSION}

Human salmonellosis is mainly attributed to food transmission (Scallan et al. 2011), reinforcing the need for control in food animals and their products. The high frequency of Salmonella enterica in pre-chill carcasses evidenced here supports the prioritizing of this hazard among those transmitted to human by unprocessed pork, which was pointed out in the risk assessment conducted by Costa et al. (2020). On the contrary and also corroborating the risk assessment results, the other two investigated bacterial hazards proved to have a very low frequency.

Table 2. Association between Enterobacteriaceae counts and Salmonella isolation on pig pre-chill carcasses in three slaughterhouses in southern Brazil

\begin{tabular}{|c|c|c|c|c|c|c|c|c|c|}
\hline \multicolumn{3}{|c|}{ Model structure } & \multirow{2}{*}{\multicolumn{3}{|c|}{$\begin{array}{c}\text { Model results for Enterobacteriaceae count } \\
\text { Solutions }\end{array}$}} & \multicolumn{4}{|c|}{ Observed data } \\
\hline \multirow{2}{*}{ Effects } & \multicolumn{2}{|c|}{ Subjects $^{\mathrm{a}}$} & & & & \multirow{2}{*}{$\begin{array}{l}\text { Salmonella } \\
\text { Prevalence } \\
\end{array}$} & \multicolumn{3}{|c|}{ Enterobacteriaceae } \\
\hline & Abattoir & Day of sample & Estimate & SE & $p$-value & & Mean & Min & Max \\
\hline Enterobacteriaceae count & All & All & 0.10 & 0.25 & 0.69 & $17.7 \%^{\mathrm{b}}$ & $0.28^{\mathrm{b}}$ & $-0.9^{b}$ & $3.06^{\mathrm{b}}$ \\
\hline \multirow{2}{*}{ Random intercepts } & $\mathrm{C}$ & 1 & 1.96 & 0.51 & 0.0002 & $61.9 \%$ & 0.25 & -0.90 & 1.94 \\
\hline & $\mathrm{C}$ & 5 & 1.57 & 0.53 & 0.0032 & $52.4 \%$ & 0.79 & -0.43 & 1.54 \\
\hline
\end{tabular}

a There are 18 subjects (sampling event), only three were statistically demonstrated; ${ }^{\mathrm{b}}$ prevalence, mean, and min-max of all data points in three slaughterhouses; $\mathrm{SE}=$ standard error.

Table 3. Distribution of Salmonella enterica serovars isolated from pig carcasses in three southern Brazilian slaughterhouses

\begin{tabular}{lcccc}
\hline \multicolumn{1}{c}{ Serovar } & \multicolumn{3}{c}{ Slaughterhouses } & C \\
\cline { 2 - 4 } Typhimurium & $\mathrm{A}$ & $\mathrm{B}$ & - & $24(38.1 \%)$ \\
Infantis & 8 & 16 & 19 & $19(30.1 \%)$ \\
Mbandaka & - & - & 7 & $7(11.1 \%)$ \\
Panama & - & - & - & $4(6.35 \%)$ \\
Hadar & 3 & 1 & 4 & $4(6.35 \%)$ \\
London & - & - & - & $2(3.2 \%)$ \\
Saintpaul & 1 & - & 1 & $1(1.6 \%)$ \\
S. O:4,5:-:1,2 & - & - & 1 & $1(1.6 \%)$ \\
Rugose morphotype & - & - & 1 & $1(1.6 \%)$ \\
TOTAL & - & 18 & 33 & 63
\end{tabular}

Table 4. Percentage distribution of antimicrobial resistance to different antimicrobials in Salmonella enterica serovars isolated from pig carcasses in three slaughterhouses of southern Brazil

\begin{tabular}{|c|c|c|c|c|c|}
\hline Antimicrobials & $\begin{array}{c}S . \text { Infantis } \\
(\mathrm{n}=17)\end{array}$ & S. Typhimurium $(\mathrm{n}=24)$ & $\begin{array}{l}\text { Other serovars } \\
\qquad(n=20)\end{array}$ & $\begin{array}{c}\text { Fisher's } \\
\text { probability (P) }\end{array}$ & $\begin{array}{c}\text { Total } \\
(n=61)\end{array}$ \\
\hline Ampicillin & $47.1^{\mathrm{a}}$ & $83.3^{b}$ & $15.0^{\mathrm{a}}$ & $<0.0001$ & 54.4 \\
\hline Ciprofloxacin & $0^{\mathrm{a}}$ & $4.2^{\mathrm{b}}$ & $0^{\mathrm{a}}$ & 0.0065 & 1.75 \\
\hline Chloramphenicol & $35.3^{\mathrm{a}}$ & $75.0^{\mathrm{b}}$ & $10.0^{\mathrm{a}}$ & $<0.0001$ & 45.6 \\
\hline Gentamicin & $0^{\mathrm{a}}$ & $54.2^{\mathrm{b}}$ & $15.0^{\mathrm{a}}$ & $<0.0001$ & 28.1 \\
\hline Nalidixic acid & $17.6^{\mathrm{a}}$ & $83.3^{\mathrm{b}}$ & $15.0^{\mathrm{a}}$ & 0.0010 & 45.6 \\
\hline Tetracycline & $35.3^{\mathrm{a}}$ & $83.3^{b}$ & $35.0^{\mathrm{a}}$ & 0.0010 & 57.9 \\
\hline Trimethoprim & 35.3 & 12.5 & 20.0 & 0.2557 & 22.8 \\
\hline Full susceptible & $41.2^{\mathrm{a}}$ & $4.2^{\mathrm{b}}$ & $55.0^{\mathrm{a}}$ & 0.0003 & 31.2 \\
\hline Multi-drug resistant & $41.2^{\mathrm{b}}$ & $83.3^{\mathrm{a}}$ & $25.0^{\mathrm{b}}$ & 0.0003 & 52.5 \\
\hline
\end{tabular}

$\mathrm{a,b}=$ Different letters in a same line differ significantly by Fisher's exact test $(\mathrm{P} \leq 0.05)$. 
Regarding Listeria monocytogenes isolation, despite none carcass has being positive, the study design used here allow us only to conclude that the prevalence in carcasses is low, i.e. below the detection power. Although frequencies above $30 \%$ have already been reported in pig carcasses in Brazil (Ferronato et al. 2012, Pissetti et al. 2012), in both studies, the high frequency of isolation was concentrated in just one slaughterhouse. The high adaptation of L. monocytogenes to moist and low temperature, which characterize the slaughterhouse environment, corroborate with the hypothesis that high frequencies in pork may be associated with poor hygiene and biofilm formation on surfaces in contact with the carcasses. Moreover, L. monocytogenes outbreaks are more often vehiculated by ready-to-eat products than by unprocessed pork, which is usually subjected to heat treatment before consumption (Valk et al. 2001, Awofisayo-Okuyelu et al. 2016). Therefore, monitoring programs of L. monocytogenes targeted to processed pork products are usually the strategy adopted by the sanitary authorities (Brasil 2009, EFSA 2018) followed by a thorough investigation of the production process in cases of detection of contaminated products.

Although Yersinia enterocolitica has been recognized as cause of foodborne disease cases in humans, particularly associated with eating raw or undercooked pork in European countries (Huovinen et al. 2010, Rosner et al. 2011), only one carcass resulted positive in this study. Pigs have shown to be a major reservoir of pathogenic Y. enterocolitica, particularly strains of bioserotype 4/0:3 (Fredriksson-Ahomaa et al. 2007). A similar scenario was reported in Brazil, and Y. enterocolitica 4/0:3 was found in $30 \%$ of tongues and tonsils from pigs at slaughter, while none of 192 samples of pork resulted positive (Paixão et al. 2012). These results corroborate to the low priority of investigation of this pathogen in a monitoring program of pig carcasses in Brazil. Similarly, Y. enterocolitica was not classified as of high risk in the scientific opinion on biological hazards transmitted by pork published in the European Union (EFSA 2011). The high frequency reported in tongue and tonsils highlights the hazard represented by the tissues associated with the head regarding the cross contamination during the pluck set removal (Borch et al. 1996). Moreover, edible tissues in the head area, such as tongue and cheek meat, are often commercialized or included in processed products. In this sense, post-fabrication interventions to be applied in the trimmings may be considered and further evaluated in future studies.

The frequency of $S$. enterica positive carcasses corroborates the prevalence in previous studies conducted in Brazil, which varied from 9.8 to 24\% (Kich et al. 2011, Silva et al. 2012, Corbellini et al. 2016, Brasileiro et al. 2017). As previously reported (Corbellini et al. 2016), there is a high variation in the frequencies among slaughterhouses and slaughter days. The model constructed considering these variations estimates prevalence values between $3.8 \%$ and $55.8 \%$, with an average prevalence similar to the observed. The day of slaughter nested within the slaughterhouse represents $31.3 \%$ of the whole variation in the Salmonella prevalence, indicating that several factors in a slaughter day may influence the number of positive carcasses. The Salmonella prevalence variation may be associated to failures in the slaughter process, which should be monitored by the profile of hygienic indicators over a time period. Actually, in our study, the median of TAM and
Enterobacteriaceae was significantly higher in Slaughterhouse C, which presented also the highest Salmonella prevalence in the pre-chill carcasses. Therefore, data of monitoring of hygienic indicators may be of outmost importance in autocontrol quality programs as well as for official auditing of slaughterhouses. Deviations in the hygienic indicators should be interpreted as an enhancement of the hazard of carcass contamination with pathogens, which may be present in the slaughtered pig or in the environment. However, there is no strict correlation between the hygienic indicator counts in a given carcass or in a given slaughter day with the isolation of Salmonella in pre-chill carcasses. Although, in a few cases the Salmonella prevalence was associated with higher Enterobacteriaceae counts in our study (Table 2), in general this association was not supported by the statistical analysis. This fact highlights that, even in slaughterhouses with a controlled hygienic process, Salmonella can present a higher prevalence in pre-chill carcasses in some days. Therefore, the monitoring programs of Salmonella in carcasses cannot be discontinued in auto-control programs and official audits, even in slaughterhouses with a good hygienic process. Another important aspect to be considered is the delivery of slaughter batches with high number of Salmonella carrier pigs or the presence of high shedders among the slaughtered pigs, since these factors have been pointed out as leading to enhancement of carcass contamination probability (Duggan et al. 2010, Silva et al. 2012, Kerouanton et al. 2019, Paim et al. 2019). In this case, other approaches targeted to the preharvest stage are needed, in order to diminish the pressure in the slaughtering process represented by a high number of Salmonella carrier pigs.

The characterization of $S$. enterica isolated in the three slaughterhouses demonstrated a significant difference among the serovars found. While $S$. Typhimurium predominated in Slaughterhouses A and B, in C this serovar was not found and most strains were identified as $S$. Infantis. The prevalence of Salmonella serovars often varies among production systems and over time (Denis et al. 2013, Colello et al. 2018). This fact reflects the multiple sources of Salmonella, which includes, associated or not, carrier animals, contaminated feed and environment (Funk \& Gebreyes 2004, Kich et al. 2005). Still, $S$. Typhimurium is often reported as the most prevalent serovar in pig and pork (Kich et al. 2011, Silva et al. 2012, Campos et al. 2019, Paim et al. 2019). Moreover, this serovar is also frequently reported in human cases and outbreaks associated with pork consumption (Campos et al. 2019). While $S$. Infantis does not figure among the most prevalent serovars identified in swine, human cases present frequently serious symptoms indicating that this serovar may be highly virulent (Almeida et al. 2013). Therefore, the serovars identified in our study highlights the need of Salmonella control for the consumer's health.

An additional growing concern in public health has been the antimicrobial resistance presented by pathogenic or non-pathogenic bacteria colonizing food animals. The hazard of transmission of these resistant bacteria to human has been considered as a factor that may contribute to failures of antibiotic treatments in human patients. Foodborne pathogens are of special relevance, since antimicrobial resistance represents an additional hazard for patients with low immunity, which will need antibiotic therapy. In this sense, a marked difference 
was observed in the resistance level of $S$. Typhimurium compared to the other serovars. Considering the first choice for antibiotic treatment of salmonellosis in humans, resistance to ciprofloxacin was displayed by $4.2 \%$ of the $S$. Typhimurium strains, while all strains of other serovars were susceptible to this drug. Moreover, $83.3 \%$ of the $S$. Typhimurium strains were resistant to nalidixic acid, which is often the first step for full resistance to fluorquinolones (Oteo et al. 2000). These results corroborate the recommendation of phasing out the use of antimicrobials highly important to human medicine in animal production (WHO 2018b). The resistance profile in general demonstrated that $S$. Typhimurium was significantly more resistant to most tested antimicrobials and presented more MDR strains in comparison to the other serovars. $S$. Typhimurium is reported as a serovar which often presents multiresistance and, therefore, besides its pathogenic potential may also carry a plethora of resistance genes (Almeida et al. 2018, McMillan et al. 2019). In recent years, genes codifying extended spectrum beta-lactamases (ESBL) or carbapenemases as well as resistance to macrolides have been emerged as a particular concern (WHO 2018b). In this regard, all tested strains were susceptible to these antimicrobial groups in agreement with other reports of very low frequency or absence of resistance to these drugs in Salmonella originated from the Brazilian swine production chain (Bersot et al. 2019, Monte et al. 2019, Viana et al. 2019). On the contrary, antimicrobials such as ampicillin, tetracycline and nalidixic acid have been often reported among the group of highest levels of resistance in food borne pathogens (Lopes et al. 2015, Almeida et al. 2018, Bersot et al. 2019, Monte et al. 2019, Viana et al. 2019). Those drugs belong to antimicrobial classes broadly used in pig production in Brazil (Dutra 2017), which justify the high level of resistance found.

\section{CONCLUSIONS}

Salmonella enterica is more prevalent in pre-chill pig carcasses than Yersinia enterocolitica and Listeria monocytogenes and thus should be prioritized in monitoring and control programs at slaughter.

Salmonella serovars varied among slaughterhouses and present significant differences in their resistance to antimicrobials.

Slaughterhouses that present higher medians of total aerobic mesophiles or Enterobacteriaceae in a monitoring period may have higher $S$. enterica prevalences as well. However, there is a high variation of $S$. enterica prevalence among slaughter days, which cannot be always related to the hygienic indicators counts observed on a given day.

Acknowledgements.- This study was carried out with the support of "Sistema Embrapa de Gestão” (SEG), “Coordenação de Aperfeiçoamento de Pessoal de Nível Superior” (CAPES), Brazil, Financing Code 001 (PNPD scholarship for E.F. Costa; MSc scholarship for A.I.A. Souza), and the "Conselho Nacional de Desenvolvimento Científico e Tecnológico" (CNPq), Brazil, (MSc scholarship for D. Paim; Undergraduate scholarship for M. Meneguzzi).

Conflict of interest statement.- The authors declare no conflict of interest.

\section{REFERENCES}

Almeida F., Pitondo-Silva A., Oliveira M.A. \& Falcão J. P. 2013. Molecular epidemiology and virulence markers of Salmonella Infantis isolated over
25 years in São Paulo State, Brazil. Infec. Gen. Evol. 19:145-151.<https:// dx.doi.org/10.1016/j.meegid.2013.07.004>

Almeida F., Seribelli A.A., Medeiros M.I.C., Rodrigues D.P., Varani A.M., Luo Y., Allard M.W. \& Falcão J.P. 2018. Phylogenetic and antimicrobial resistance gene analysis of Salmonella Typhimurium strains isolated in Brazil by whole genome sequencing. PLos One 13(8):e0201882. <https://dx.doi. org/10.1371/journal.pone.0201882> <PMid:30102733>

Arguello H., Carvajal A., Naharro G., Rodicio M.R., Martin M.C. \& Rubio P. 2013. Sero- and genotyping of Salmonella in slaughter pigs, from farm to cutting plant, with a focus on the slaughter process. Int. J. Food Microbiol. 161(1):44-52. <https://dx.doi.org/10.1016/j.ijfoodmicro.2012.11.013> <PMid:23261811>

Awofisayo-Okuyelu A., Arunachalam N., Dallman T., Grant K.A., Aird H., McLauchlin J., Painset A. \& Amar C. 2016. An outbreak of human listeriosis in England between 2010 and 2012 associated with the consumption of pork pies. J. Food Protect. 79(5):732-740.<https://dx.doi.org/10.4315/0362028X.JFP-15-456><PMid:27296419>

Bersot L.S., Cavicchioli V.Q., Viana C., Burin R.C.K., Camargo A.C., Pinto J.P.A.N., Nero L.A. \& Destro M.T. 2019. Prevalence, antimicrobial resistance, and diversity of Salmonella along the pig production chain in Southern Brazil. Pathogens 8(4):204. <https://dx.doi.org/10.3390/pathogens8040204> <PMid:31652972>

Borch E., Nesbakken T. \& Christensen H. 1996. Hazard identification in swine slaughter with respect to foodborne bacteria. Int. J. Food Microbiol. 30(1/2):9-25. <https://dx.doi.org/10.1016/0168-1605(96)00988-9>

Brasil 2003. Métodos analíticos oficiais para análises microbiológicas para controle de produtos de origem animal e água. Instrução Normativa no 62/2003, Diário Oficial da União de 18/09/2003, Seção 1, p.14, Brasília, DF. Available at <http:// www.agricultura.gov.br> Accessed on Jan., 2012.

Brasil 2007. Exportações de carne suína para os estados-membros da União Europeia. Circular no 130/2007/CGPE/DIPOA, Ministério da Agricultura, Pecuária e Abastecimento (MAPA), Brasília, DF. Available at <http://www. agricultura.gov.br/sislegis > Accessed on Dec., 2015.

Brasil 2009. Programa de controle de Listeria monocytogenes em produtos de origem animal prontos para consumo. Instrução Normativa n.9/2009, Diário Oficial da União de 8/09/2009, Seção 1, Brasília, DF. Available at <http://www.agricultura.gov.br/assuntos/inspecao/produtos-animal/ controle-de-patogenos/arquivos-controle-de-patogenos/in_09-_de_8_ de_abril_de_2009.pdf> Accessed on May 5, 2020.

Brasil 2018. Plano de ação nacional de prevenção e controle da resistência aos antimicrobianos, no âmbito da agropecuária. Ministério da Agricultura, Pecuária e Abastecimento (MAPA), Brasília, DF. Available at <http:// www.agricultura.gov.br/assuntos/insumos-agropecuarios/insumospecuarios/programas-especiais/resistencia-antimicrobianos/arquivos/ copy2_of_publ_panagro_web.pdf> Accessed on May 5, 2020.

Brasileiro A.C.M., Santos M.A.S., Sá C.V.G.C., Rodrigues C.S. \& Haddad J.P.A. 2017. National prevalence of Salmonella spp. in pork slaughterhouses under Federal Inspection in Brazil, 2014/2015. 12th International Symposium on the Epidemiology and Control of Biological, Chemical and Physical Hazards in Pigs and Pork, Foz do Iguaçu, PR, p.55-58.

Buncic S., Nychas G.J., Lee R.F., Koutsoumanis K., Hebraud M., Desvaux M., Chorianopoulos N., Bolton D., Blagojevic B. \& Antic D. 2014. Microbial pathogen control in the beef chain: recent research advances. Meat Sci. 97(3):288-297. <https://dx.doi.org/10.1016/j.meatsci.2013.04.040> $<$ PMid:23688797>

Cameron-Veas K., Fraile L., Napp S., Garrido V., Grilló M.J. \& Migura-Garcia L. 2018. Multidrug resistant Salmonella enterica isolated from conventional pig farms using antimicrobial agents in preventative medicine programmes. Vet. J. 234:36-42. <https://dx.doi.org/10.1016/j.tvjl.2018.02.002> <PMid:29680391>

Campos J., Mourão J., Peixe L. \& Antunes P. 2019. Non-typhoidal Salmonella in the pig production chain: a comprehensive analysis of its impact 
on human health. Pathogens 8(1):19. <https://dx.doi.org/10.3390/ pathogens8010019><PMid:30700039>

CLSI 2015. Performance standards for antimicrobial disk and dilution susceptibility test for bacteria isolated from animals. CLSI document VET01-S3, Second Informational Supplement, Clinical and Laboratory Standards Institute, Wayne. 128p.

CLSI 2016. Performance standards for antimicrobial susceptibility testing. CLSI document M100-S26, Clinical and Laboratory Standards Institute, Wayne. 256p.

Colello R., Ruiz M.J., Padín V.M., Rogé A.D., Leotta G., Padola N.L. \& Etcheverria A.I. 2018. Detercion and charcaterization of Salmonella serotypes in the production chain of two pig farms in Buenos Aires province, Argentina. Front. Microbiol. 9:1370.<https://dx.doi.org/10.3389/fmicb.2018.01370> <PMid:30002649>

Corbellini L.G., Bianco Júnior A., Costa E.F., Duarte A.S.R., Albuquerque E.R., Kich J.D., Cardoso M. \& Nauta M. 2016. Effect of slaughterhouse and day of sample on the probability of a pig carcass being Salmonella-positive according to the Enterobacteriaceae count in the largest Brazilian pork production region. Int. J. Food Microbiol. 228:58-66. <http://dx.doi. org/10.1016/j.ijfoodmicro.2016.03.030><PMid:27107299>

Costa E.F., Cardoso M., Kich J.D. \& Corbellini L.G. 2020. A qualitative risk assessment approach to microbial foodborne hazards in Brazilian intensive pork production: a step towards risk prioritization. Microbial Risk Anal. 15(20):100105. <https://dx.doi.org/10.1016/j.mran.2020.100105>

Denis M., Houard E., Fablet A., Rouxel S. \& Salvat G. 2013. Distribution of serotypes and genotypes of Salmonella enterica species in French pig production. Vet. Rec.173(15):370. <https://dx.doi.org/10.1136/vr.101901> <PMid:24106251>

Drummond N., Murphy B.P., Ringwood T., Prentice M.B., Buckley J.F. \& Fanning S. 2012. Yersinia enterocolitica: a brief review of the issues relating to the zoonotic pathogen, public health challenges, and the pork production chain. Foodborne Pathog. Dis. 9(3):179-189. <https://dx.doi.org/10.1089/ fpd.2011.0938><PMid:22217012>

Duggan S.J., Mannion C., Predergast D.M., Leonard M., Fanning S., GonzalesBarron U., Egan J., Butler F. \& Duffy G. 2010. Tracking Salmonellla status of pigs and pork from lairage through the slaughter process in the Republic of Ireland. J. Food Protect. 73(12):2148-2160. <https://dx.doi. org/10.4315/0362-028x-73.12.2148> <PMid:21219731>

Dutra M. 2017. Uso de antimicrobianos em suinocultura no Brasil: análise crítica e impacto sobre marcadores epidemiológicos de resistência. Doctoral Dissertation, Faculdade de Medicina Veterinária e Zootecnia, Universidade de São Paulo. Available at <https://teses.usp.br/teses/disponiveis/10/10134/ tde-31012018-121740/pt-br.php> Accessed on Apr. 16, 2020.

EFSA 2011. Scientific opinion on the public health hazards to be covered by inspection of meat (swine). EFSA J. 9(10):2351. <https://dx.doi. org/10.2903/j.efsa.2011.2351>

EFSA 2018. Listeria monocytogenes contamination of ready-to-eat foods and the risk for human health in EU. EFSA J. 16(1):5134. <https://dx.doi. org/10.2903/j.efsa.2018.5134>

FAO 2000. Manual on meat inspection for developing countries. FAO Animal Production and Health Paper, Food and Agriculture Organization of the United Nations, Rome.

Ferronato A.I., Pellegrini D.C.P., Guerra P. \& Cardoso M. 2012. Distribuição de grupos clonais de Listeria monocytogenes em carcaças e no ambiente de matadouros frigoríficos de suínos. Arch. Vet. Sci. 17(3):42-49. <https:// dx.doi.org/10.5380/avs.v17i3.24940>

Fredriksson-Ahomaa M., Stolle A. \& Stephan R. 2007. Prevalence of pathogenic Yersinia enterocolitica in pigs slaughtered at a Swiss abattoir. Int. J. Food Microbiol. 119(3):207-212. <https://dx.doi.org/10.1016/j. ijfoodmicro.2007.07.050>
Funk J. \& Gebreyes W. A. 2004. Risk factors associated with Salmonella prevalence in swine farms. J. Swine Health Prod. 12(5):246-251.

Ghafir Y., China B., De Zutter L. \& Daube G. 2008. Hygiene indicator microorganisms for selected pathogens on beef, pork, and poultry meats in Belgium. J. Food. Prot. 71(1):35-45. <https://dx.doi.org/10.4315/0362028x-71.1.35><PMid:18236660>

Huovinen E., Sihvonen L.M., Virtanen M.J., Haukka K., Siitonen A. \& Kuusi M. 2010. Symptoms and sources of Yersinia enterocolitica-infection: a casecontrol study. BMC Infect. Dis. 10:122. <https://dx.doi.org/10.1186/14712334-10-122><PMid:20487529>

ISO 2007. Microbiology of food and animal feeding stuffs: horizontal method for the detection of Salmonella spp. IS06579:2002/Amd. 1:2007, International Standard Organization, Geneva. 9p.

Kerouanton A., Souchaud F., Houdayer C., Houard E., Nagard B., Guionnet J.M., Fougeroux A., Paboeuf F. \& Denis M. 2019. Pigs infected experimentally with the same dose of monophasic variant of SalmonellaTyphimurium exhibit different shedding levels. 13th International Symposium on the Epidemiology and Control of Biological, Chemical and Physical Hazards in Pigs and Pork, Berlin, p.157-159.

Kich J.D., Coldebella A., Albuquerque E.R., Cardoso M., Corbellini L.G. \& Costa E.F. 2019. Modernização da inspeção sanitária em abatedouros de suínos: inspeção baseada em risco: opinião científica. Documentos 204, Embrapa Suínos e Aves, Concórdia, SC.

Kich J.D., Coldebella A., Mores N., Nogueira M.G., Cardoso M., Fratamico P.M., Call J.E., Fedorka-Cray P. \& Luchansky J.B. 2011. Prevalence, distribution, and molecular characterization of Salmonella recovered from swine finishing herds and a slaughter facility in Santa Catarina, Brazil. Int. J. Food Microbiol. 151:307-313. <https://dx.doi.org/10.1016/j.ijfoodmicro.2011.09.024>

Kich J.D., Mores N., Piffer I.A., Coldebella A., Amaral A., Ramminger L. \& Cardoso M. 2005. Fatores associados à soroprevalência de Salmonella em rebanhos comerciais suínos. Ciência Rural 35(2):398-405. <https:// dx.doi.org/10.1590/S0103-84782005000200024>

Lopes G.V., Pissetti C., Pellegrini D.C.P., Silva L.E. \& Cardoso M. 2015. Resistance phenotypes and genotypes of Salmonella enterica subsp. enterica isolates from feed, pigs annd carcasses in Brazil. J. Food Protect. 78(2):407-413. <https://dx.doi.org/10.4315/0362-028X.JFP-14-274><PMid:25710159>

Lumley T. 2020. Package 'survey'. Version 3.37. Available at <https://cran.rproject.org/web/packages/survey/survey.pdf> Accessed on Mar. 10, 2020.

McDermott P.F., Tyson G.H., Kabera C., Chen Y., Li C., Folster J.P., Lam C., Tate H.P. \& Zhao S. 2016. Whole-genome sequencing for detecting antimicrobial resistance in nontyphoidal Salmonella. Antimicrob. Agents Chemother. 60(9):5515-5520. <https://dx.doi.org/10.1128/AAC.01030-16> $<$ PMid:27381390>

McMillan E.A., Gupta S.K., Williams L.E., Jové T., Hiott L.M., Woodley T.A., Barrett J.B., Jackson C.R., Wasileko J.L., Simmons M., Tillman G.E., McClelland M. \& Frye J.G. 2019. Antimicrobial resistance genes, cassettes, and plasmids present in Salmonella enterica associated with United States food animals. Front. Microbiol.10:832. <https://dx.doi.org/10.3389/fmicb.2019.00832> <PMid:31057528>

Monte D.F., Lincopan N., Berman H., Cerdeira L., Keelara S., Thakur S., Fedorka-Cray P.J. \& Landgraf M. 2019. Genomic features of high-priority Salmonella enterica servoars circulating in the food production chain, Brazil 2000-2016. Sci. Reports 9:11058. <https://dx.doi.org/10.1038/ s41598-019-45838-0>

Oteo J., Aracil B., Alós J.I. \& Gómez-Garcés J.L. 2000. High rate of resistance to nalidixic acid in Salmonella enterica: its role as a marker of resistance to fluoroquinolones. Clin. Microbiol. Infect. 6(5):273-276. <https://dx.doi. org/10.1046/j.1469-0691.2000.00058-3.x> <PMid:11168127>

Paim D.S., Pissetti C., Vieira T.R., Werlang G.O., Costa E.F., Kich J.D. \& Cardoso M. 2019. Enumeration, antimicrobial resistance and typing of Salmonella entrica: profile of strains carried in the intestinal contentes of pigs at 
slaughter in Southern Brazil. Acta Sci. Vet. 47:1636. <https://dx.doi. org/10.22456/1679-9216.89668>

Paixão R., De Gobbi D.D.S., Raimundo D.C., Hofer E., Matte M.H. \& Moreno A.M. 2012. Characterization of Yersinia enterocolitica 4/0:3 isolated from slaughterhouses and pork in the State of São Paulo, Brazil, and clinical cases in humans. In: De Almeida A. \& Leal N. (Eds), Advances in Yersinia Research - Advances in Experimental Medicine and Biology. Vol. 954. Springer, New York.

Pearce R.A., Bolton D.J., Sheridan J.J., McDowell D.A., Blair I.S. \& Harrington D. 2004. Studies to determine the critical control points in pork slaughter hazard analysis and critical control points systems. Int. J. Food Microbiol. 90(3):331-339. <https://dx.doi.org/10.1016/s0168-1605(03)00333-7> $<$ PMid:14751688>

Pissetti C., Werlang G.O., Biesus L.L., Kich J.D. \& Cardoso M. 2012. Detecção de Salmonella enterica e Listeria monocytogenes em carcaças suínas na etapa de pré-resfriamento. Acta Scient. Vet. 40(4):1071.

Rosner B.M., Stark K., Höhle M. \& Werber D. 2011. Risk factors for sporadic Yersinia enterocolitica infections, Germany 2009-2010. Epidemiol. Infect. 140(10):1738-1747. <https://dx.doi.org/10.1017/S0950268811002664> $<$ PMid:22313798>

SAS 2012. Package 9.3. SAS Institute Inc., Cary, NC.

Scallan E., Hoekstra R.M., Angulo F.J., Tauxe R.V., Widdowson M., Roy S.L., Jones J.L. \& Griffin P.M. 2011. Foodborne illness acquired in the United States-major pathogens. Emerg. Infect. Dis. 17(1):7-15. <https://dx.doi. org/10.3201/eid1701.P11101> <PMid:21192848>

Signorell A. 2020. Package ‘DescTools'. Version 0.99.32. Available at $<$ https:// cran.r-project.org/web/packages/DescTools/DescTools.pdf> Accessed on Mar. 10, 2020.

Silva L.E., Dias V., Ferronatto A., Guerra P., Berno L., Triches N., Kich J.D., Corbellini L.G. \& Cardoso M. 2012. Longitudinal dissemination of Salmonella enterica clonal groups through the slaughter process of Salmonellapositive pig batches. J. Food Protect. 75(9):1580-1588. <https://dx.doi. org/10.4315/0362-028X.JFP-11-515><PMid:22947464>

Silva N., Junqueira V.C.A., Silveira N.F.A., Taniwaki M.H., Santos R.F.S. \& Gomes R.AQ.R. 2010. Manual de Métodos de Análise Microbiológica de Alimentos e Água. 4⿳a ed. São Paulo, Varela.

Valk H., Vaillant V., Jacquet C., Rocourt J., Le Querrec F., Stainer F., Quelquejeu N., Pierre O., Pierre V., Desenclos J.C. \& Goullet V. 2001. Two consecutive nationwide outbreaks of listeriosis in France, October 1999 - February 2000. Am J. Epidemiol. 154(10):944-950. <https://dx.doi.org/10.1093/ aje/154.10.944><PMid:11700249>

Viana C., Sereno M.J., Pegoraro K., Yamatogi R.S., Call D.R., Bersot L.S. \& Nero L.A. 2019. Distribution, diversity, virulence genotypes and antibiotic resitance for Salmonella isolated from a Brazilian pork production chain. Int. J. Food Microbiol. 310:108310. <https://dx.doi.org/10.1016/j. ijfoodmicro.2019.108310>

Wang X., Biswas S., Paudyal N., Pan H., Li X., Fang W. \& Yue M. 2019. Antibiotic resistance in Salmonella Typhimurium isolates recovered from the food chain through National Antimicrobial Resistance Monitoring System between 1996 and 2016. Front. Microbiol. 10:985. <https://dx.doi.org/10.3389/ fmicb.2019.00985><PMid:31134024>

Weagant S.D. \& Feng P. 2001. Yersinia, p.421-428. In: Downes F.P. \& Ito K. (Eds), Compendium of Methods for Microbiological Examination of Foods. 4th ed. American Public Health Association, Washington D.C.

WHO 2018a. Listeriosis. World Health Organisation. Available at <https:// www.who.int/news-room/fact-sheets/detail/listeriosis> Accessed on Dec. 7, 2019.

WHO 2018b. Antimicrobial resistance. World Health Organisation. Available at <https:// https://www.who.int/news-room/fact-sheets/detail/ antimicrobial-resistance> Accessed on Dec. 7, 2019. 